\title{
Research on the Direction and Path of Computer Education Teaching Reform in the Information Age
}

\author{
Wang Peiyi \\ Zhengzhou Infant Normal School, Zhengzhou, Henan, China, 450000
}

\begin{abstract}
Keywords: Information background; computer education; teaching reform; direction; approach

Abstract: Computer network has become an inseparable and important part of modern society. The development of computer network technology plays an important role in promoting the development of society. This paper discusses the direction and ways of computer education and teaching reform under the background of informationization, analyzes the significance of computer education in teaching reform, the direction of computer teaching reform, and the development path of computer education and teaching, aiming to improve the teaching level of computer courses.
\end{abstract}

The development and advancement of social network information technology has prompted the society to gradually increase the application and dependence of information technology. "Informationization" has become a symbolic term in today's society. In line with the development requirements of the society, the teaching tasks of computer education are also becoming more and more arduous. Computer is not only an important tool for students' life and study, but also an important skill that students can master and apply to the field of work and employment. Teaching reform is an effective way to practice modern educational concepts. Computer education also needs to pay attention to the concept of teaching reform in its own teaching work. Deepen to promote the sustainable development of computer education ${ }^{[1]}$.

\section{The importance of computer education for teaching reform}

\subsection{Promote the improvement of students' computer practice and application ability}

The application of computer technology has become the central technology for the development of various industries in modern society. The expansion of computer application can effectively improve the efficiency of production and life behavior, and can make social life more diverse and rich. Computer education to carry out teaching reform can improve the practical characteristics of computer education, take students' computer technology application as the focus of education, pay attention to students' independent technical practice, and then improve students' computer application ability, and realize computer professional knowledge to students' individual ability. Transform to promote the continued development of computer education ${ }^{[2]}$. 


\subsection{Promoting the sustainable development of university computer education}

The traditional computer education mode of the university can no longer meet the development requirements of the modern social situation for the cultivation of high-quality computer talents. The teaching pressure of higher computer education has also continued to increase. Practicing teaching reform is one of the important teaching tasks of the university. The deepening of the teaching reform of computer education can focus on the learning content of students, pay attention to students' understanding and personal application of teaching content, and apply the reform of teaching reform to establish an advanced education system for university computer education. University computer teaching should form a collective cultivation mechanism that comprehensively applies knowledge and shares knowledge. Teaching reform will improve the teaching objectives of higher computer education, teachers' teaching ideas and teaching methods, and promote the continuous development of computer education in universities ${ }^{[3]}$.

\section{Teaching status of computer education in universities}

\subsection{The teaching content of computer education in universities is too lagging}

Computer education activities in universities are generally based on the content of teaching materials. The preparation of textbooks from editing, revision, editing, printing to input into the education market needs to go through a certain period of time. The development of computer technology can be described as ever-changing, and the application content and application form of computer technology are also in the continuous development, it is reflected that the teaching content in some computer course textbooks has shown lag in the application of technology. The technical learning of students in the classroom teaching process has been difficult to meet the actual application needs, and the backwardness of teaching content has restricted the development of computer education in universities.

\subsection{University computer education is difficult to reflect the technical application focus}

The so-called "specialization of the industry" is that technology learning can have its targeted content and direction, and can achieve the level of technical application in its field. The current computer education in universities reflects the lack of technical application focus. Computer education in universities is divided into computer-based teaching and non-computer-based computer teaching. From the perspective of computer professional teaching, computer professional technology is mainly embodied in software technology and hardware technology. Many universities only set software engineering for separate professional settings. The remaining technical fields are unified into computer science; from the non-computer major computer teaching, the teaching content is more extensive, and many majors are using the same textbook version and teaching content $^{[4]}$. These problems have led to the disconnection between computer education and the professional development of students. Whether it is for computer majors or non-computer majors, students will not be able to expand the application of computer technology in practice. University computer application occupation distribution as shown in Figure 1. 


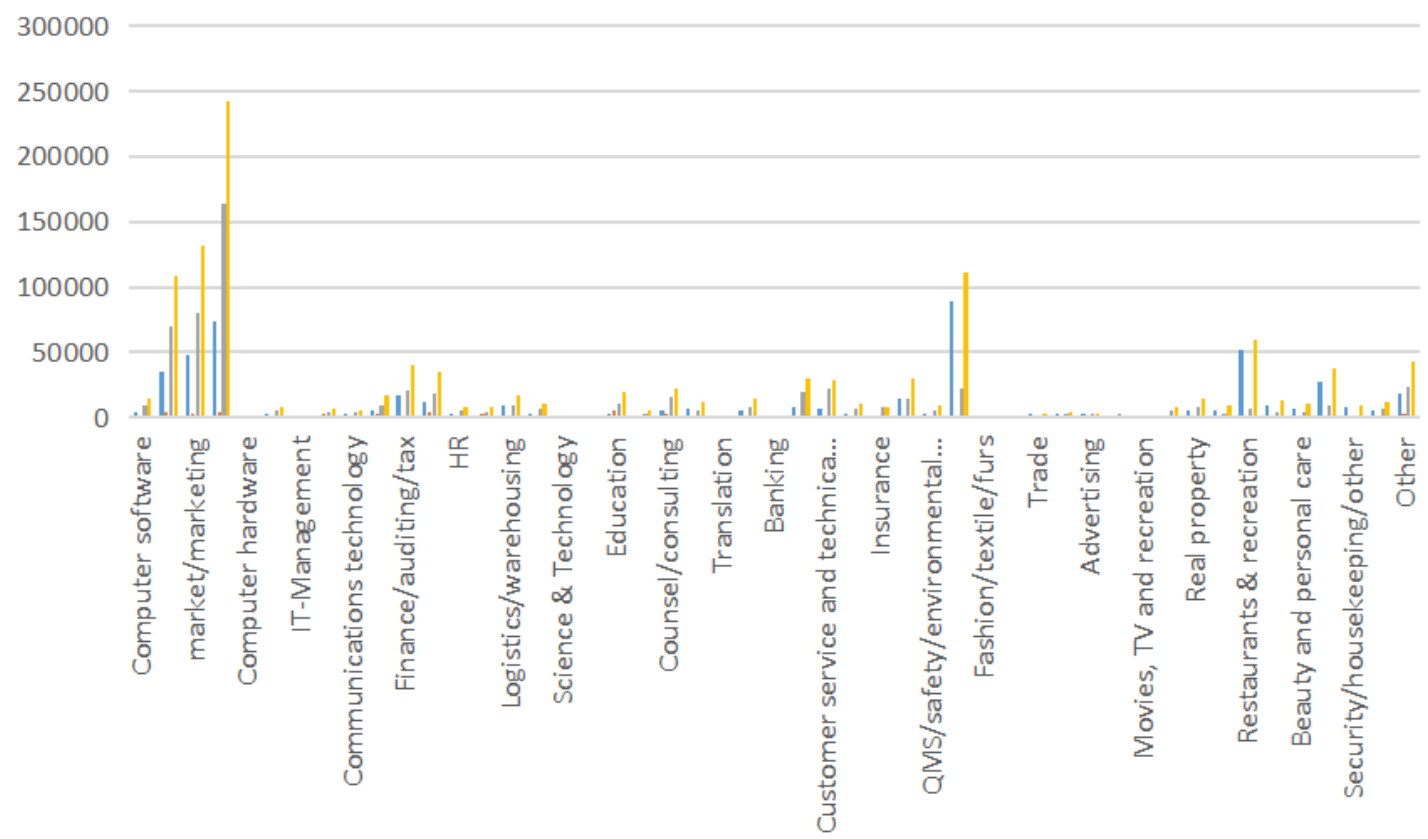

Figure 1 University computer application occupation distribution

\subsection{The form of computer teaching is too single}

The university conducts computer classroom teaching, and generally adopts the classroom teaching process of teacher explanation demonstration and student imitation practice. The teacher talks according to his own teaching ideas, while the students will take notes and focus on the blind. It seems that the classroom teaching atmosphere is strong, and the students can follow the teacher's rhythm to operate, but when the teacher combines the teaching content to arrange the corresponding teaching for the students Tasks, students from the help of teachers and textbooks, will show no sense in the independent operation. Some students also have a certain rejection of the teacher's monotonous teaching methods. The participation and coordination of classroom teaching activities are poor. There is a lack of necessary communication and interaction between teachers and students, and classroom teaching goals are difficult to achieve ${ }^{[5]}$.

3. The direction of computer education and teaching reform under the background of information

There is an inextricable link between the teaching content, teaching forms and teaching measures of computer education. The professional development of students and the individualized development of students are all issues that computer education should consider. The current development of social computer technology can be described as leaps and bounds. The application scope and application methods of computer technology are gradually showing diversified characteristics. Computer education also needs to pay attention to the cultivation of diverse talents. Different student individuals will make their attention to computer technology different. The deepening of teaching reform in computer education requires attention to the individualized development of students, focusing on students' learning demands and maximizing students' satisfaction. Personalized growth. Because students' different concerns about computer technology applications will make them show interest in different learning content, computer education activities to meet students' concerns and interest needs, can effectively improve students' learning efficiency. At the same time, it also helps to promote students' self-learning activities and 
inquiry-based learning behaviors. If computer education adopts unified teaching content and teaching methods, it is easy for some students to have less interest in the teaching process and limit the realization of computer education goals. At the same time, it also limits the cultivation of high-level technical talents.

\section{The development path of computer education and teaching under the background of information}

\subsection{Fine division of computer education}

The essence of computer education aims to cater to the development requirements of the modern information society, so that students can master the application of computer technology in their future work and life. Therefore, universities need to divide the teaching of computer education in a refined way. For computer professional teaching, it can be divided into software development direction, hardware research and development direction, computer network security direction, computer education, etc. For computer teaching of non-computer major, it is necessary to effectively combine computer technology with professional content, such as computer technology and the integration of garden engineering related majors, the integration of computer technology and administrative management, the integration of computer technology and accounting related majors. All sectors of modern society are actively advocating the application of computer technology to improve their work efficiency, the professional operation of professional application software such as medical and health care, financial management, etc., and the basic skills that practitioners need to have, through the fine division of educational courses, Help students to master practical computer technology in their own professional fields, enhance their post competitiveness and adaptability, and ensure that computer course learning can be truly applied. The development path of computer education and teaching under the background of informationization is shown in Figure 2.

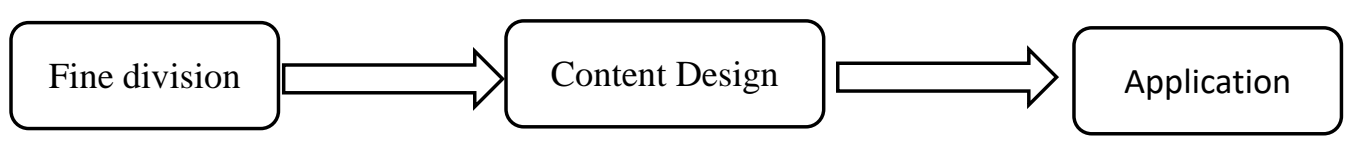

Figure 2 Development path of computer education

\subsection{Conducting scientific teaching content design}

To carry out computer education activities, it is necessary to carry out scientific teaching content design, optimize and integrate the existing computer education courses, try to compress the theoretical courses as much as possible, give sufficient teaching time for practical teaching, and learn the computer technology for students. The main purpose is to be able to Skilled application of computer technology to solve practical life and work problems, so practical education should be the top priority of computer education. The design of computer courses should be based on the fine division of courses. It is necessary to integrate more practical teaching contents and design scientific and reasonable teaching contents so that students can learn the teaching content with practical application value through classroom teaching and ensure the scientific content of teaching content. Sex and timeliness.

\subsection{Application of diverse computer teaching mode}

Based on the educational development direction of personalized education and developmental education, computer education needs to enrich the teaching mode, giving students more learning 
experience and improving their interest in computer courses. Teachers can apply various teaching modes such as hierarchical teaching and project-based teaching to the course teaching process, combined with the teaching content to apply flexible teaching methods, set classroom teaching tasks based on students' learning foundation and learning interests, and adopt various teaching methods. Improve students' participation in classroom teaching activities, realize teachers' teaching appeals and links to students' learning demands, pay attention to students' learning process and learning effectiveness, pay attention to students' application ability training, improve students' learning efficiency, and help to promote teaching goals.

\subsection{Construction of a faculty for high-level computer education}

Teachers are the basis for carrying out teaching activities, guiding teaching directions, and practicing teaching behaviors. Computer education requires teachers not only to have rich professional knowledge, but also to require teachers to have educational awareness in the information age, and to guide students through effective educational skills. More boring teaching content. Schools need to pay attention to the construction of high-level teachers, so that teachers must not only have a solid foundation in computer education, but also combine the needs of the society for the application of computer technology, expand the content of professional teaching, guide students' professional inquiry spirit, and enhance their teaching. The ability to improve the quality of computer education in universities also helps to promote the development of the computer education industry.

\section{Conclusion}

The development background of the information age requires the school to attach importance to computer education. The teaching reform has clearly defined the development direction for computer education. Individualized education and practical education will be the focus of future computer education. Schools need to pay attention to the construction of high-level teachers. Under the conditions of teaching conditions, the computer education curriculum is divided into fine lines, and the computer technology is connected with the students' professional subjects to ensure that students can apply computer technology. Teachers need to pay attention to the reform of teaching content and teaching mode, attach importance to the cultivation of students' practical application ability, improve the effectiveness of classroom teaching, and thus train more computer talents to serve the development of society.

\section{References}

[1] S.E. Nwana,T.O. Ofoegbu,C. I. Egbe. Availability and Utilization of ICT Resources in Teaching Computer Education in Secondary Schools in Anambra State, Nigeria [J]. Mediterranean Journal of Social Sciences, 2017, 8(5).

[2] Olivera Iskrenovic-Momcilovic. Using Computers in Teaching in Higher Education [J]. Mediterranean Journal of Social Sciences, 2018,9(4).

[3] Etem Yeşilyurt,Abdulhak Halim Ulaş,Durdağl Akan. Teacher self-efficacy, academic self-efficacy, and computer self-efficacy as predictors of attitude toward applying computer-supported education [J]. Computers in Human Behavior, 2016,64.

[4] Shawn Funk,Donald H. Lee. Optical Head-Mounted Computer Display for Education, Research, and Documentation in Hand Surgery[J]. Journal of Hand Surgery, 2016, 41(1).

[5] Ahlam Lee. Determining the effects of computer science education at the secondary level on STEM major choices in postsecondary institutions in the United States [J]. Computers \&amp; Education, 2015, 88. 